\title{
The Effects of Teleworking on Housework Division and Well-Being of Couples
}

\author{
Eleftherios Giovanis \\ University of Verona, Department of Economics, Via dell'Artigliere 8, 37129, Italy \\ Email: giovanis95@gmail.com eleftherios.giovanis@univr.it
}

\begin{abstract}
This study examines the relationship between teleworking, gender roles and happiness of couples using data from the British Household Panel Survey (BHPS) and the Understanding Society Survey (USS) during the period 1991-2012. Various approaches are followed, including Probit-adapted fixed effects, multinomial Logit and Instrumental variables (IV). The results support that both men and women who are teleworkers spend more time on housework, while teleworking increases the probability that the household chores examined in this study, such as cooking, cleaning ironing and childcare, will be shared relatively to those who are nonteleworkers. In addition, women are happier when they or their spouse is teleworker, as well as, both men and women are happier when they state that the specific household chores are shared. Thus, women teleworkers may be happier because they can face the family demands and share the household chores with their spouse, increasing their fairness belief about the household division allocation and improving their well-being, expressed by happiness.
\end{abstract}

Keywords: Gender Roles; Household Production; Telecommuting; Teleworking; Well-Being JEL codes: D1, D13, J16, I31 


\section{Introduction}

Teleworking is defined as the working environment where employees work at home instead at offices or employer's premises (Lim et al., 1997). Teleworking has long been studied, but has been extensively examined since the beginning of 1990s. However, the circumstances have been changed since then, and the economic and technological developments of the last years that took place have led to necessity for further research on this employment type. One factor that explains the birth of teleworking is the global economy which was characterised by the exchange of goods, while now is heavily dominated by information. Another major factor is the fast and impressive boost in improvement of microchips, telecommunications systems and computing among other elements of these technologies. These factors made possible for a person to work at a distant location away from the employer's premises (Nilles, 1975; 1999).

Work family issues and gender roles have become increasingly important trends in the last 30 years. Socio-economic trends as the increasing participation of women in the labour force, greater number of working single-parents and the increasing care of an ageing population provide new responsibilities and challenges to both women and men to work-family balance and commitments (Lerner, 1994; Marks, 1996). An increasing number of women and men nowadays are involved in work and family arrangements, which were largely unknown for the parents' and the past generations (Barnett and Rivers, 1996; Hochschild, 1997). Along with these new challenges the traditional allocation of family and work is breaking down by gender (Willinger, 1993; Barnett and Rivers, 1996). So far the understanding of the work-family nexus remains limited, thus the research based on which policies and practices can be developed to help individuals through the new work family arrangements, remains also limited.

Based on previous researches, specific domestic and household tasks are identified by masculinity and femininity (Coltrane, 1989; Warde and Hetherington, 1993). Thus, the introduction and allocation of production into home can have different consequences for male and female teleworkers. Nevertheless, very little is known how teleworking affects men and women and how they reconcile the demands of work and household production and how teleworking is associated to well-being. Another fundamental point is both gender divisions and the diversity of household types within which gender relationships are embedded are essential. (Anderson et al., 1994; Benjamin and Sullivan, 1996). Nevertheless, these studies do not explore the relationship between teleworking, housework division and couples' well-being. 
Our research will contribute to this existing work using a comprehensive panel dataset which is the British Household Panel Survey (BHPS) and the Understanding Society Survey (USS).

The aim of this study is to examine how teleworking affects the housework division of men and women and their well-being. More specifically, this study aims to explore whether teleworking has positive effects on the balance of family-work time and obligations, household production allocation and improvement on well-being. In addition, women's career path can be negatively influenced more than men by institutional barriers, such as gender-pay gap, job loss during the pregnancy, insufficient maternity benefits for childrearing activities, insufficient public kinder-gardening (Becker, 1981; Hersch and Stratton, 1994; Waldfogel, 1998). Therefore, teleworking can be an option to provide conditions for women caring relationships with their children, and career goals at home and for men contributing to the housework. Increase flexibility will facilitate the management of work and family together. The housework production refers to activities, such as cooking, cleaning, ironing and shopping, while couples with children are considered additionally to explore the relationship between teleworking, happiness and childcare time allocation. From previous research studies, it has been found that parents with young children tend to be more likely to work from home or to telework due to child needs and costs, as well as, because the parents wish to maximise their time spent with children (Han, 2004; Barnett and Gareis, 2007; Wight et al., 2008). Therefore, exploring the effects of teleworking on gender roles and well-being would give valuable insights for future policy implications related to work-family balance, distribution of household production allocation and well-being.

Using panel data, the fixed effects regressions allow us to capture the individual effect which summarises the influence of unobserved variables that may have persistent effect on the dependent variable. More specifically, we apply four main approaches. The first is the conventional fixed effects models where the association between teleworking and housework hours is examined. Then we use the multinomial Logistic regression with fixed effects where the relationship between gender role attitudes and teleworking is explored. The third model refers to the Adapted-Probit method which allows the estimation of regression models with fixed effects when the dependent variable is ordered and refers to the happiness. Fourth, we apply an instrumental variable approach to examine the effects of teleworking on housework hours and happiness.

The structure of the paper is the following: In section 2 short literature review is presented. In section 3 the methodology followed is discussed while in section 4 the data sample used in 
the analysis is presented. In section 5 the empirical results are reported while in the final section the concluding remarks are discussed.

\section{Literature Review}

In the literature review two main views have been analysed; the rational view and the gender role framework. Based on the rational view the more hours than a person spends on work and family the more conflict he/she will perceive (Keith and Schafer, 1984). Greenhaus et al. (1987) found that extensive time commitment to work is positively associated with work family conflict. Given that family work, house chores and childcare require many hours, we expect that the employed women have not enough time for family activities (Bryson et al., 1978). However, the question in this study is whether those who are teleworkers spend more time on family work. Earlier research studies have found that women spend overall more hours than men on family obligations and household chores (Denmark et al., 1985). On the other hand, the gender role framework departs from the rational view. Even though most men and women report that the family is more valuable than work and even there have been many changes in the household production allocation the last 50 years, the traditional gender roles persist. The study by Bauernschuster and Rainer (2010) explored and compared the gender role attitudes between Eastern and Western Germany and they found that these attitudes are less traditional in Eastern Germany because of the different political systems suggesting that the gender roles might diverge in the western world.

In this study, the hours of housework are explored, as well as, the perception of the respondents on whether the housework is their main responsibility or a shared process. More specifically, critics of exchange theory argue that, is more practical and fruitful to examine couples' perceptions of fairness instead of focusing on the relationship between the division of household chores- domestic production and marital and life satisfaction (Thompson, 1991; Pina and Bengston, 1993). Pina and Bengston (1993) find that the way that wives perceive the amount of support and the help they receive from their husband is more important in determining the happiness than the actual division of labour expressed in hours of housework. Thus, we expect that even in the case where the share of household tasks is not equal in terms of housework hours, this does not imply that the women perceive it as unfair, as the findings in the empirical section show. Teleworking can be an alternative or a substitution tool to 
parental leave benefits, or a complementary policy which can allow the parents to divide time on childcare and labour market with flexible working hours or part time allocation provided by this flexible employment type. For instance, a study by Ozdamar (2015a) found a significant relationship between child health and parental leaves, suggesting that the traditional social policies might not be efficient. In a similar study the female political participationrepresentation and the allocation of public spending on family allowances differs (Ozdamar, 2015b). Therefore, by exploring teleworking as a distributional factor, within an intrahousehold collective approach, we can explore how teleworking divides the bargaining process between the couples, providing especially to the women the option to be employed and to spend time on housework and childcare.

Various studies explored the effects of teleworking and working at home on performance, employee's satisfaction and compensation rates. Bloom et al. (2015) exploited data from an experiment at Ctrip, a NASDAQ-listed Chinese travel agency with 16,000 employees. Call center employees who volunteered to the experiment, and which is called "working from home" (WFH), randomly assigned either to work from home or at the office for a period of nine months. Bloom et al. (2015) found that working from home led to a 13 per cent performance increase, associated with fewer breaks and sick days, and resulted to an increase of calls per minute by 4 per cent. Similarly, Dutcher (2012) conducted a unique experiment derived from the student population at Florida State University and the participants were randomly assigned to participate in the XS/FS lab on campus or outside the lab. XS/FS lab consists of a diverse group of research scholars and various experiments are conducted. The subjects in both locations were given information about how to login to a website which was setup to conduct the experiment and the population consists of 125 participants; 63 in the lab and 62 outside the lab and the 52 per cent of the sample was male. Their results suggest that while the out of lab environment reduced productivity in the dull task by $6-10$ percent, the creative task productivity increased by 11-20 per cent. Oettinger (2011) explored the homebased employment and the wage penalty associated with it. More specifically, it is assumed that home working is a job attribute requested more by workers with high opportunity costs spending away from home and when in-person interaction with other colleagues and supervisors is not required. In the equilibrium, the workers who value this attribute most will be matched with employers who can provide this at the lowest cost. Therefore, the wage penalty will exist if working from home is valuable to the marginal home-based worker and at the same time costly for the marginal employer to provide this attribute. The empirical analysis relies on data derived from the 5 percent Public Use Microdata Samples (PUMS) of the U.S. Census of 
Population for the years 1980, 1990, and 2000. The main findings of the study are that the overall home-based employment share nearly doubled and the mean home-based wage penalty fell by about 30 percentage points over the period 1980-2000.

One study relevant to ours is the study by Dockery and Bawa (2014) who employed data from the Household, Income and Labour Dynamics in Australia Survey (HILDA) for 11 waves over the years 2001-2011. The authors found that there is a positive association between working from home and the employees' satisfaction with the flexibility to balance work and non-work commitments. This is related to our study, since the relationship between teleworking, household production allocation and happiness is explored. Nevertheless, this study goes one step further and explores the cross-effects of teleworking on housework division and couples' overall well-being. In addition, Dockery and Bawa (2014) provide evidence that employees working at home are more likely to receive a lower rate of compensation that the respective employees put in at the workplace. This rate is equal by about $\$ 1$ per hour less than the return to hours spent in the office. Overall, Dockery and Bawa (2014) argue that working from home is considered by employees as a positive job attribute that provides flexibility to balance work and non-work commitments. The study by Li et al. (2014) provides a detailed survey of previous studies exploring the relationship between non-standard working schedules and child well-being. For instance, the study by Rapoport and Le Bourdais (2008) has shown that working at home in general is associated with more time devoted to household chores for mothers and allows fathers to spend more time for social activities and family meals. Therefore, the study of the teleworking and working from home effects on household production allocation and child well-being can be considered for future research.

This paper adds to the previous literature by exploring the link between teleworking, household chores and well-being of couples. In addition, using panel data analysis it is possible to include the history of the individuals into a regression model, providing more accurate inference of the model parameters, greater capacity of capturing the complexity of human behaviour than the cross-sectional data analysis. Moreover, panel data contain information on inter-temporal dynamics and they allow for controlling the effects of missing or unobserved variables. 


\section{Methodology}

3.1 Theoretical framework

The model presented in this section is a utility discrete choice model based on the models proposed by Gronau (1977), Van Soest (1995) and the collective model developed by Chiappori $(1988,1992)$.

However, most of these studies are based on cross-sectional analysis which present the issues discussed earlier, and we discuss in the methodology section. Also, this study investigates the link between teleworking, gender roles and overall utility (happiness). Thus, the analysis is limited on the investigation of the above linkage, and no effort examining the labour supply decisions and behaviour takes place. Based on that, the analysis is limited to households with two adult members-couples. In the classical Gronau household production model, it is assumed that the household members share one common utility function, where they derive utility from leisure $t_{m}^{l}$ for man and $t_{f}$ for woman, from market goods $X_{M}$ and commodities produced at home $H$, such as cooking, washing, shopping, taking care of children. In the Gronau model it is assumed that market goods and goods produced in the household are perfect substitutes. The utility function will be:

$U=U\left(X_{M}+H, t_{m}^{l}, t_{f}^{l}\right)$

$U$ is assumed that it is twice continuously differentiable and strictly concave. The household production $H$ is a function of the time spent or the share of the couple on housework defined as $t^{h}$ for male and $t^{h}$ for female and auxiliary inputs $X_{H}$. In that case two variables are used; the first is the time-hours per week- spent for housework, while the second variable examined is the gender role attitudes and they refer on whether the couples share the household chores, such as cooking, shopping and taking caring care of the children. The auxiliary inputs $X_{H}$ refer on intermediate inputs as food for preparing meals, and using car or public transportation for shopping.

$H=H\left(X_{H}, t_{m}^{h}, t_{f}^{h}\right)$

The household budget constraint consists of the non-labour income $I$ and the labour income expressed by the weekly wages $w_{m}$ and $w_{f}$ for male and female respectively, and market labour 
supply in hours per week defined as $t^{w}$ for male and $t^{w} f$ for female. The household budget constraint will be:

$I+w_{m} t_{m}^{w}+w_{f} t_{f}^{w}=X_{M}+X_{H}$

Relation (3) entails the risk of selecting households that both spouses may have a relatively high productivity in the market and low productivity in household production and vice versa. However, this model is presented as introduction, where in the points followed teleworking will be included. The time constraint for each member will be:

$T=t_{i}^{w}+t_{i}^{h}+t_{i}^{l}$, for $i=m, f$

Including teleworking it will be:

$U=U\left(X_{M}+H, t_{m}^{l}+t e l_{m}\left(t_{m}^{h}\right), t_{f}^{l}+t e l_{f}\left(t_{f}^{h}\right)\right)$

The first order conditions of utility function (5) with respect to housework hours $t^{h} m$ and $t^{h}$ are:

$$
\begin{gathered}
\frac{\partial U}{\partial H} \frac{\partial H}{\partial t_{m}^{h}}=\frac{\partial U}{\partial H} \frac{\partial H}{\partial X_{H}} w_{m}\left(1-t e l_{m}^{\prime}\left(t_{m}^{h}\right)\right)+\lambda_{m} \\
\frac{\partial U}{\partial H} \frac{\partial H}{\partial t_{f}^{h}}=\frac{\partial U}{\partial H} \frac{\partial H}{\partial X_{H}} w_{f}\left(1-t e l_{f}^{\prime}\left(t_{f}^{h}\right)\right)+\lambda_{f}
\end{gathered}
$$

In (6)-(7) $\lambda m$ and $\lambda f$ denote shadow prices of the inequality constraints on labour time. If both partners participate in the labour force then it is $\lambda m=\lambda f=0, w_{m}>0, w_{f}>0$ and the interior solution can be simplified into the following partial optimisation problem:

$$
\underset{\max 0 \leq t_{m}^{h}, t_{f}^{h} \leq T}{H}=H\left(t_{m}^{h}, t_{f}^{h}, X_{H}\right)+w_{m} t e l_{m}\left(t_{m}^{h}\right)+w_{f} t e l_{f}\left(t_{f}^{h}\right)-w_{m} t_{m}^{h}-w_{f} t_{f}^{h}-X_{H}
$$

Then the first order conditions will be: 


$$
\begin{aligned}
& \frac{\partial H}{\partial t_{m}^{h}}=w_{m}\left(1-t e l_{m}{ }^{\prime}\left(t_{m}^{h}\right)\right) \\
& \frac{\partial H}{\partial t_{f}^{h}}=w_{f}\left(1-t e l_{f}{ }^{\prime}\left(t_{f}^{h}\right)\right)
\end{aligned}
$$

In this case the inclusion of teleworking shows that the household members will choose the housework level where the marginal product of their housework equals their wage which is adjusted with this part of the housework activity through teleworking perceived as leisure or allocating time for housework (for instance the time spent for commuting at work can be invested to leisure or to household-domestic work). Teleworking may increase the time spent also on household chores, since the person is located at home and there is more available time since commuting either does not exist for the teleworker homeworkers or it is much less for those who spend some days only in the employer's premises. Otherwise the household may decide to purchase the household chores, which information is available as the data sample and it is described in more details in the next section. More specifically, according to the classical household production model the household production $Z$ is an increasing function of the $i$ 's member work in household production $h_{i}$, and $h_{i}$ increases at a decreasing rate. Then the member $i$ will choose to increase the housework until a point for example $t^{h}{ }_{i}{ }^{*}$, where the marginal product in household production is equal to the wage and it is $\partial H / \partial t^{h}{ }_{i}=w_{i}$. However, including the teleworking, which ranges between 0 (office-based workers) to 1 (teleworker homeworkers), the housework is more than the classical household production model would predict. For example, in this case the hours of household production is $t^{h_{i}{ }^{* *}}$, and it is $t^{h_{i}}{ }^{* *}>t^{h_{i}}$ , thus the difference between $t^{h}{ }_{i}^{* *}$ and $t^{h}{ }_{i}{ }^{*}$ can be interpreted as the effect of teleworking on housework production. Nevertheless, the association of teleworking, household domestic production-chores and well-being in the economics literature has not been explored.

Concluding the impact of teleworking may depend on various circumstances. First, it is assumed that men who are teleworkers, are more likely to share the housework with their partners, or at least to contribute more than men who are non-teleworkers and similarly for women. This assumption can be important and has various implications. Regarding men who are teleworkers and spend more time on housework will allow women to devote more time on their career, share the household chores with their partners and increase their happiness. On the other hand, women who are teleworkers and they spend more time on housework may be less happy. But they can be happier, since they can cope with the family demands and at the same 
will be able to participate in the labour market, facing less stress and having more available time, substituting the time lost in commuting at work.

We should notice that the hours of housework are included into the analysis. However, an additional analysis on whether the respondent or the partner is contributing more, less or equally on specific household chores, such as shopping, ironing, cleaning, cooking and childcare, takes place. The reason is that some house chores in our sample can be main responsibility of women, while others can be the main responsibility of men. Although women continue to be responsible for the majority of housework, few may perceive it as unfair. As we mentioned in the literature review, it can be more useful to examine couples' perceptions of fairness additionally to the housework hours.

\subsection{Panel Regressions}

In this section the panel regressions are described. As we discussed in the previous parts, the first aim of this study is to explore the association between teleworking and housework hours and the estimated model will be:

$$
H H_{i, j, t}=a_{0}+a_{1} t e l_{i, j, t}+a_{2} \log \left(y_{i, j, t}\right)+\alpha^{\prime} z_{i, j, t}+\mu_{i}+\theta_{t}+l_{j}+l_{j} T+\varepsilon_{i, j, t}
$$

$H H$ is the housework hours for individual $i$, in location $j$ and time $t$. tel indicates whether the individual $i$ is teleworker, $\log (y)$ is the logarithm of the household income, $z$ is a vector of personal and household characteristics, discussed in the data section. Set $\mu_{i}$ denotes the individual-fixed effects, $l_{j}$ is a location-residence fixed effects, $\theta_{t}$ is a time-specific vector of indicators for the day and month the interview took place and the survey wave, while $l_{j} T$ is a set of area-specific linear time trend, which controls for unobservable, time-varying characteristics in the area, which can affect the propensity to telework, such as distance to employer's premises ${ }^{1}$. We estimate model (11) using fixed effects. Next the regression model which examines the relationship between gender roles and teleworking is:

$$
G R_{i, j, t}=a_{0}+a_{1} t e l_{i, j, t}+a_{2} \log \left(y_{i, j, t}\right)+\alpha^{\prime} z_{i, j, t}+\mu_{i}+\theta_{t}+l_{j}+l_{j} T+\varepsilon_{i, j, t}
$$

\footnotetext{
${ }^{1}$ A Heckman selection model for propensity to telework has been estimated to explore the selection bias of teleworkers and non-teleworkers. The results show that there is no selection bias in the sample and are not reported here.
} 
$G R$ denotes the gender roles and the division of housework, and the possible answers are: whether the individual does mainly the housework, whether his/her partner does mainly the housework, both share the housework, somebody else does the housework and are discussed in more details in the data section. The remained variables are defined as in regression model (11). We estimate regression (12) with multinomial Logistic method and fixed effects, which is a classification method that generalizes logistic regression to multiclass problems, (eg. with more than two possible discrete outcomes as is the gender roles). This will allow us to estimate whether teleworking increases the probability that the couples share the housework, and to examine the hypothesis that spouses who are teleworkers may spend more time in householddomestic production. Finally, regression (12) is estimated using the happiness as dependent variable and is the following:

$$
H P_{i, j, t}=a_{0}+a_{1} t e l_{i, j, t}+a_{2} \log \left(y_{i, j, t}\right)+\alpha^{\prime} z_{i, j, t}+\mu_{i}+\theta_{t}+l_{j}+l_{j} T+\varepsilon_{i, j, t}
$$

$H P$ denotes the happiness for individual $i$, in area $j$ and time $t$, while the remained variables are the same with those defined in regressions (11)-(12). However, vector $z$ includes additionally the gender role attitudes, to explore the relationship between household production allocation and couples' well-being. One method to estimate model (13) would be the ordered Logit and Probit with random effects. However, a fixed effects framework is not feasible using these models into a panel data structure. The method followed in this study is the Probit OLS introduced by van Praag and Ferrer-i-Carbonell (2004) which rescales the categorical dependent variable and derives $Z$-values of the standard normal distribution that correspond to cumulative frequencies of the original categories (see Cornelissen, 2006, for an example).

As we mentioned in the previous sections, the analysis in this study relies on a panel dataset. Panel data analysis offers many advantages over alternative methods, including cross-sectional and time-series analysis. More degrees of freedom are available and it is possible to derive more accurate inference of the estimated coefficients. Also, with panel data we can capture at a greater degree the complex human behaviours, than we can do using cross-sectional or time series data. Panel data analysis is useful to account for the heterogeneity in the population, exploring behaviours of the individuals from past information we have for the same individual across time (Hsiao et al., 1995). This is not possible with the cross-sectional data, since they cover many individuals but only for one period, which is like a snapshot. On the other hand, 
time-series allow for the investigation of dynamics, since they refer to a period of time longer than one, but the disadvantage lies on the fact that we can explore only one unit or individual. Therefore, we cannot infer to a sample of individuals, which is not practical for the derivation of conclusions that can be helpful for policy makers and that may offer information about the society. A strength of the panel data is the evaluation of specific programs and policies. In this case, the analysis with cross-sectional data will suffer as those receiving the treatment are different from those who do not. Therefore, it is not possible to observe simultaneously the effects to the individual receiving the treatment, before and after the implementation of the program or policy. This is also not feasible with the time-series data, because they refer to one individual, as we mentioned earlier. This is very important and related to our study, since we want to compare the teleworkers, where we assume is the treatment group and teleworking is the policy or program, and the control group, which we assume is the non-teleworkers (Hsiao et al., 1995). Another very important benefit of the panel data analysis is that we can control for the impact of omitted variables that may be correlated with the explanatory variables. Panel data contain information on both the history of the individual and the inter-temporal dynamics and allow us to control for unobserved variables. Furthermore, it allows the uncovering of dynamic relationships which is not efficient with time-series data (Pakes and Griliches, 1984; Hsiao et al., 1995). Following the same individual over a long time, as in this study, it is possible to explore the impact of various socio-economic characteristics, and their change, on the outcome of interest. These characteristics include among others, employment and marital status, labour participation, education, age, health.

\section{Data}

The dataset used in this study is the British Household Panel Survey (BHPS), which is a panel survey started since 1991 and completed in 2009 covering 18 waves. The BHPS sample was later included in the new survey, Understanding Society, which started in 2008. This survey contains a totally new sample of individuals and households, but also it keeps the same BHPS sample. Therefore, our analysis will be limited on this sample, as our purpose is to have a panel data where the same individual is followed across time. BHPS is a classic example of household panel surveys designed to address and examine a wide range of research topics, 
including income, poverty, labour, well-being, health, education, housing, household formation, fertility, social and political attitudes and values among others.

BHPS has the following statements on the housework division that are helpful to observe which gender is responsible at doing different house chores: Who does the grocery, who does the cooking, who does the cleaning, who does the washing/ironing and who is responsible for the childcare. The possible answers are mainly myself, mainly the partner, shared/both and someone else, which can be some other member from the household, a friend, a relative or someone by payment. Regarding the family "environment" the question is who contributes to the child care replying to the same answers as above. Finally, there is a quantitative variable, hours per work in housework, which will be used as an additional dependent variable in the regression (11) discussed in the methodology section.

Regarding well-being the survey includes a question about happiness, which is an ordinal variable measured on a 4-point scale and the specific phrasing of the question is the following "Have you recently been feeling reasonably happy, all things considered". In addition, life satisfaction could be considered, but it is measured only after the $6^{\text {th }}$ wave, while happiness is available since the beginning of BHPS. The health status is an ordinal variable answering on whether the respondent's health is very poor/poor/fair/good/excellent.

The regressions control for both partners' characteristics. More specifically, partners' weekly working hours, age, education level, job status, health status and the personal labour income, are included into the regressions. Household characteristics include the household size and house tenure. The personal income may be an important factor as it can capture the bargaining power of partners. For instance, women with higher income may have a higher bargaining power regarding the household-domestic labour allocation. The number or the age of children could be examined too, but it is highly correlated with the household size. However, one assumption is that in some cases the women or both couples may choose to telework if they want to take care of the children. Nevertheless, this can be applied also to the elder members who are need of care. Therefore, we explore the couples with and without children, but allowing the possibility having an elder member.

Finally, the regressions control for the day of the week, the month of the year and the wave of the survey, and for residence location which is expressed by the local authority district. The latter can capture unobserved characteristics associated with the area, such as traffic affecting the time needed to attend at work etc. Moreover, the day of the week is important, especially for those who telework at both home and employer's premises, which captures the effects of teleworkers who stay at home or commute at work. We should notice that the waves in the 
analysis are totally 20 where 18 are derived from BHPS and 2 from the Understanding Society Survey (USS). While there are four waves for USS over the period 2009-2013, we use the second and fourth wave, for the years 2010 and 2012, since the questions about the gender role attitudes are available only in these waves.

In table 1 the summary statistics for gender roles, housework, personal and household income, teleworking and happiness are reported. The sample of analysis refers only to married and those who live as a couple. The percentage of teleworkers is 11.22 , while the 3.42 is homebased only teleworkers. More men are involved in teleworking than women at 13.5 and 9 per cent respectively. The teleworkers who work more than one place, meaning that they spend some days in employer's premises, is 7.80 per cent, where the 10.31 and 5.22 per cent consist of men and women respectively. We should notice that one of the possible answers in the gender role attitudes questions is the paid help, except for the question of the childcare responsibility, where the answer is someone else, meaning that could be another member of the family, paid help or help from relatives.

In addition, as we can see in table 1, the gender roles are not homogenous. More specifically, the 40.47 of the non-teleworkers men answer that shopping role is shared while it is reduced at 36.91 per cent for the men teleworkers. This can be explained that shopping is an outdoor activity, thus it may be more likely that those who work in the employers' premises will combine shopping with work, i.e. after finishing their work. On the other hand, a different situation is presented for cooking. The 11.70 of the teleworkers men states that is mainly responsible for cooking reducing the responsibility of the partners at 57.13 from 59.57 and increasing the shared responsibility at 29.42 per cent from 26.89 for non-teleworkers, while the 11.89 of the non-teleworking men sample is mainly responsible for cooking. We note a similar situation for women. Finally, childcare presents quite different results than the rest of the gender role attitudes. More specifically, the proportion of men who are mainly responsible for childcare is significantly higher than the respective percentage of the remained gender role attitudes, 30-35 per cent versus 5-15 per cent. The probability for women being mainly responsible for the childcare is decreased from 33.47 per cent for men non- teleworkers to 30.47 per cent for men who are teleworkers. Moreover, the shared proportion is increased from 22.33 for non-teleworking men to 25.46 for teleworking men. Also, the 1.28 of nonteleworking men are mainly responsible for the childcare, while the percentage is increased at 5.16 for teleworking men.

However, teleworking for women implies additional childcare responsibility, as the percentage for teleworking women who are mainly responsible for the child is 32.86 , while the 
respective percentage for women non-teleworkers is 30.61 and it is statistically significant, according to the $p$-values in the brackets. In addition, the shared housework is reduced from 21.03 for non-teleworking women to 18.23 for women who telework. Regarding the hours devoted in housework, in panel $\mathrm{F}$ of table 1, both men and women who are teleworkers on average spend two more hours for housework than non-teleworking men and women. Overall, the summary statistics show that based on the theoretical model teleworking both men and women spend more time to housework. On the other hand, shared housework proportion is higher for men teleworkers, while is lower for women teleworkers. In addition, the average labour market hours of men teleworkers and non-teleworkers are 37.28 and 38.25 , while the respective average weekly hours for women are 25.6 and 28.5. In panel F, the monthly average personal and household income, and the average happiness in a scale 1-4 are reported. Men who telework have on average a higher personal (labour-wage) income by 120 than nonteleworking men, while women teleworkers have almost the same income with nonteleworking women. Similarly, the household income is similar between the two groups. The average happiness of both men and women who telework is higher than those who are nonteleworkers.

\section{(Insert table 1)}

In table 2 the correlation matrix of household chores, weekly housework hours, happiness and income is presented. We should note that the household chores shopping, cooking, cleaning, ironing and childcare are binary variables taking value 1 whether the housework is shared and 0 otherwise. This is not the best representation as there is heterogeneity between teleworkers, as well as, between men and women. Nevertheless, the purpose is to see the association between the shared housework and the other variables. In table 2 the association between teleworking and housework hours is positive. The association of teleworking and whether shopping is shared is negative, as we presented in table 1, which can be explained by the fact that shopping is an outdoor activity. We can see this by the positive association between teleworking and whether sharing cooking, ironing and cleaning. A positive correlation between teleworking and happiness and income is presented.

Regarding the housework hours, these are negatively associated with the probability that the housework is shared, which can be explained by the fact that people with higher income are more likely to work more hours and thus to contribute less in the household production. In 
addition, happiness and shared household production are positively associated. This may indicate that people who share the household production are happier. Similarly, additional housework hours are negatively associated with happiness, which can be derived by the fact that sharing the housework implies less housework hours.

(Insert table 2)

\section{Empirical Results}

In this section the regression results are presented. In columns (1)-(2) in table 3 the housework hours fixed effects estimates are reported, while in columns (3)-(4) the instrumental variables (IV) estimates using Two Stage Least Squares (2SLS) are reported for men and women respectively. Following a similar approach to the studies by Pischke (2011) and Pischke and Schwandt (2012) who used industry codes as instruments for income, in this study teleworking is instrumented by the socio-economic class, and the industry codes of the spouses' occupation. More specifically, the former is a categorical variable, which refers on whether the respondent is a high or low skilled professional, high or low professional, manager, trader, skilled or unskilled worker. The second variable refers to the industry code defined by the standard occupational classification (SOC) which is a list of classifying workers into occupational categories, such as agriculture, analysts, banking and finance, marketing education, tourism and others. We should notice that since both variables are categorical, the dummies indicating each category are obtained as instruments.

The argument of using the socio-economic class as an instrument for teleworking is that higher skilled workers or managers can work from home some days of the week using technological tools, such as internet, online storage systems, programming and data analysis tools. The argument of using the second variable, SOC, is that some industries are more likely to offer teleworking schemes, such as banking, finance, education and marketing relative to other industries, including farming, agriculture and mining. It is assumed that these variables are correlated to teleworking, but they do not affect directly the household production allocation or happiness. The IV estimates are slightly higher than the ones derived by the OLS. When men telework are more likely to spend on average 1.1-1.3 more hours per week than their respective non-teleworkers counterparts. Similarly, according to the estimates in table 3, when women telework, men spend less hours in housework; however, the coefficient is 
insignificant in both OLS and IV estimates. Regarding the women, their housework time is increased when they telework and they spend on average 1.5 and 1.9 hours more than the women who do not telework. Women are more likely to spend less in household chores, when their spouse is teleworker by $0.4-0.5$ hours on average than the women whose partner does not telework. According to the weak instrument test and its associated p-value the null hypothesis is rejected, concluding that the socio-economic class and the industry codes of the spouses' occupation can be a proper instrument. Moreover, based on the Sargan statistic the exogeneity of the instrumental variables is confirmed.

(Insert table 3)

In table 4 the results for cooking derived from the multinomial fixed effect Logit model are reported. The base outcome is mostly partner, while the paid only role is not presented as it is not the main point of interest and in the most cases is insignificant. For men and women, the association between teleworking and being mainly responsible is insignificant. Men are more likely to state that cooking is shared when either they or their partner is teleworker. On the other hand, for the women's sample, the teleworking coefficients are negative and significant. So far the estimates confirm the theoretical model, that both spouses are more likely to spend more time on household production. More specifically, the probability for men to state that the cooking is a shared process is higher by 0.025 and 0.12 when they and their spouse is teleworker. Regarding women who or their partner are teleworkers are less likely to state that the cooking is a shared process by 0.12 and 0.18 , indicating that teleworking can be associated with additional hours on household production process.

Increases in the labour income and number of market hours of men decreases the probability that they will be mainly responsible for cooking or that it is a shared process This can be explained by the additional hours spent on work leaving them with less available time for this gender role. On the other hand, increases on the income may be associated with additional bargaining power. However, a higher wage is usually associated with additional working hours. On the contrary, increases on the respective factors of women increases the probability that men will be mainly responsible for cooking for the same reasons mentioned before. The difference is the reply on whether cooking is shared between the couples. More specifically, we see that when the labour income of women increases, both partners reply that it is more likely to be shared among them. However, increases on woman's labour income is negatively 
associated with the probability occurrence that cooking is main responsibility of women. The same findings hold for the other gender roles in table 5; however, these characteristics, as the remained factors are not presented because the conclusions remain the same.

Age has significant effects with similar interpretation while both men's and women's employment status and house tenure coefficients are insignificant. However, employment status can be insignificant as the regressions condition on other factors, including income and education. Another important finding from table 4 is that those with first degree or no education are less likely to state that cooking is shared, while women with no qualification are more likely to believe that they are mainly responsible, while men do not. This can be explained by the fact that education, as the labour income, is an important factor determining the bargaining power of each member into the household as it happens in society too. Also, low educated women may believe that couples should not contribute the same, that man is the main breadwinner and women should be involved more in housework, as it is observed in families with traditional gender roles. Finally, health status is an important factor that determines the household production allocation. More specifically, for the men sample, when their spouse reports a very poor level of health status are more likely to share the cooking or to be the main providers. Similarly, the women who state that their general health status is very poor are less likely to state that are mainly responsible for cooking and more likely to state that cooking is a shared production process. This shows that teleworking can have a very important implication on family matters since partners can participate at the labour market and at the same time they can allocate more time on household chores providing support to the unhealthy or disabled members of the household.

In table 5, the estimates for the remained household chores are reported. Nevertheless, only the coefficients of teleworking are presented, as the remained factors present a similar sign as in the case of cooking in table 4, leading to the same concluding remarks. Regarding the men sample when they or their partner are teleworkers are more likely to state that shopping is not shared. This can be explained by the fact when they or their partner are teleworkers they spend more time in indoor housework activities. More specifically, keeping all the other variables in the model constant, the probability that men will state that shopping is a shared process is less by 0.11 and 0.18 respectively for men and women teleworkers and relative to the base reference which is mostly my partner. Similarly, the respective probabilities for women are 0.22 and 0.17 for men and women teleworkers respectively. Also, women are more likely to state that shopping is their main responsibility when their partner teleworks and less likely when women are teleworkers. 
When the woman is teleworker, man is less likely to state that he is mainly responsible for cleaning by 0.2395 relatively to mostly my partner indicating that women spend more time on cleaning. On the other hand when man is teleworker the probability to state that cleaning is shared is higher by 0.0233 than non-teleworkers relatively to the base category mostly my partner. The same belief holds for women when man is teleworker, while when woman is teleworker, she is more likely to be the main responsible person for cleaning by 0.4246 than her partner, confirming the theoretical assumptions of the model. The same holds for the woman's sample and the gender roles of ironing and childcare. Regarding men when they are teleworkers are more likely to be mainly responsible for ironing by 0.2344 respectively than the men non-teleworkers relatively to the base reference that the chores are mainly responsibility of their partners. The respective coefficient for women is 0.16 , while when they telework are less likely to state that ironing is shared by 0.1749 than their respective nonteleworkers counterparts and relatively to the statement that mainly their partner is involved in the specific gender role. Men's statement on whether are responsible for the childcare is significant and positive when they telework and are more likely to state that they are the main responsible by 1.018 than the men non-teleworkers relatively to the base category that their partner is the main responsible person for this gender role. Similarly, the coefficient of men teleworking on whether childcare is shared is 0.11 indicating that are more likely to state that it is a shared process than men who do not telework. This confirms the theoretical assumptions of the model that teleworking is associated with additional hours spent on household division. Also, women whose partners is teleworker, state that they are mainly responsible less by 0.16 than the women whose partner is not teleworker, indicating that it is more likely that men will be involved in this gender role. On the other hand, when men are teleworkers, women are more likely to state that childcare is a shared process by 0.235 .

\section{(Insert tables 4-5)}

In table 6 the happiness regressions for men and women are reported. The regressions in table 6 include the gender role attitudes and the base outcome chosen is whether the respondent replies that he/she is mainly responsible for the specific household chore. In addition, the housework hours are included. We should notice that the gender roles may be correlated; however, the results remain robust when each gender role is examined separately. In columns (1)-(2) the happiness regressions for the couples having children are reported, while the 
respective regressions for couples without children are reported in columns (3)-(4). Regarding men, the results show that being teleworkers or not is insignificantly related to happiness. On the other hand when their spouse is teleworker are more likely to report higher levels of happiness. More specifically, men whose partner is teleworker report a higher level of happiness on average by 0.05-0.07 based on the columns (1) and (3) of table 6.

About the gender roles, the results are insignificant except for shopping, ironing and childcare, where men who stated that the housework chores are shared are more likely to be happier. All the other outcomes are insignificant, except for ironing, where men who answered that this role is main responsibility of their spouse are more likely to report higher levels of happiness. In addition, in column (3) the men with children are more likely to be happier when they state that the cooking is a shared process.

On the other hand, when both are teleworkers, women are happier, where housework hours have a negative and significant impact on happiness of women with children. In that case women are happier by 0.045 when their spouse is teleworker. Women teleworkers are more likely to report higher levels of well-being on average by 0.0134 than the women nonteleworkers, while the respective average effect for women without children is 0.0117 . Regarding shopping, cooking, ironing and childcare, women are happier when the housework on these roles is mainly responsibility of their partners. About all the gender roles, women who stated that housework is shared are more likely be happier. The other outcomes are insignificant while the results remain similar when the household size is included.

Regarding the housework hours, increases on household production are associated with lower levels of happiness; however, is not clear whether these increases of fairness beliefs are result of sharing the housework with their spouse or not. The question in this case is whether teleworkers are more likely to share the household, especially men, while women teleworkers may contribute more into the household production affecting their utility. Nevertheless, women teleworkers, or even men, may choose to telework because they prefer to spend more time on household chores and activities, as well as, on leisure activities. Since teleworking allows for flexibility in working time schedule, people may spend time on their favourite activities, such as sharing the housework with their spouse, spending more time on childcare and other activities.

In table 7 the adapted Probit-IV estimates for the happiness functions are reported, where teleworking is instrumented with the socio-economic class and the industry codes of the partners' occupation, as in table 3. The IV estimates are similar with those derived by the adapted Probit-OLS in table 6, where the teleworking has slightly stronger effects on couples' 
happiness, when the IV approach is considered. According to the weak test it is concluded that the null hypothesis of the weak instruments is rejected, while according to the p-values of the Sargan statistic, the null hypothesis of no endogeneity is accepted.

\section{(Insert tables 6-7)}

The findings of this study offer various theoretical and empirical applications for research. The future studies can explore the teleworking into an intra-household resource allocation and labour supply models, considering also household domestic production and leisure. This framework will allow to explore whether teleworkers, women or men, contribute more to household domestic production, as we explored here. Also, studies can examine how the couples participate in the leisure, the labour market, and how they share the household expenditures among them and their children. This study explored only the happiness of adults who are teleworkers or not. However, future studies may explore the relationship of parents who are teleworkers and the happiness of their children. If they devote more time to children caring, over their childhood and during their course of life as teenagers, their well-being can be affected as well. Within the intra-household collective modelling framework, the relationship between teleworking and fertility can be explored. Since, the reduction of fertility is an issue in the western societies, with various effects on the society, such as the increase of an ageing population and burden to the pension and health care system, teleworking may be a solution to fertility. More specifically, women who want to have children, but also a career and time to cope with both family and job demands, teleworking can be a possible solution. Furthermore, future studies may explore the collective household model including teleworking and disability. In this case, the investigation can be related with teleworking and the caring of disabled members of the household.

Another field of teleworking related with well-being is that it may offer control over work and autonomy, allowing the employees to adjust their working schedules according to their needs and demands. This will help them to cope with family and work demands, increasing the productivity and job performance. These additional benefits may improve also the job satisfaction due the benefits of teleworking and may lead to improvement of productivity. Therefore, one field of future research is the investigation of those linkages, and specifically, how teleworking is related with working schedule, job satisfaction, productivity and overall 
well-being, expressed by happiness and life satisfaction, of the employee. Thus, future research can explore whether teleworking improves job satisfaction and performance, and how is related to well-being of the employees and their families. In line with this area, the effects of the teleworking on the job search of disabled people, their labour participation, their performance and overall well-being is another interesting point of research. Studies should investigate whether teleworking offers opportunities for disabled people to participate in the labour market, as they may face discrimination in the workplace, and limitation to attend the employer's premises, because of physical and mobility problems.

Additionally, a field of research includes the investigation of the relationship between teleworking and firm performance in terms of costs savings in terms of office, equipment and other labour related costs. Also, if teleworking increases job performance and productivity, the effects can be beneficial for the companies. Thus, teleworking can have multiple effects, including the well-being of employees and their families' well-being, but also impact on the employers and workplaces, improving their performance and productivity. Within the industrial organisation research field, teleworking can be explored in terms of the type of work, such as whether the job includes creative or dull duties. More specifically, future studies can explore whether teleworking is related to jobs that contain dull or creative duties, or whether teleworkers are more productive in creative jobs. Since, the main point of interest in society is the improvement of the well-being, teleworking may have beneficial effects to employees, families and employers.

Another area of research includes the urban planning and overall well-being of the society. More precisely, teleworking can be a tool for traffic and air pollution reduction, improving the overall well-being of people. This includes improvement on public health, due to reduction of air pollution and gas emissions from the cars, but also mental and psychological improvement on well-being. The latter refers to reduction of stress due to commuting from home to work and traffic congestion.

\section{Conclusions}

The results showed that teleworkers spend more time on household production, while women whose partner is teleworker are more likely to state that household chores are shared increasing their overall well-being. In addition, the results show that the members that report 
lower levels of health status are more likely to get support on household chores. This shows that teleworking can be a useful tool and alternative policy for supporting ill and disabled family members, which has not been explored in the literature.

Concluding teleworking can be an alternative tool with various policy implications and benefits for families, employers and society overall. It can be a solution of problems related to work and family balance. Since one of the main aims of the policy makers is the improvement of well-being, which is the ultimate goal of people, teleworking may be another option. It can lead to work-family life balance and thus in higher levels of happiness. This can have impact on other life events and conditions, such as improved health and time management and allocation in leisure activities, including reading, sports, attending to concerts, taking courses and others. Additionally, teleworking and household allocation can have additional benefits on job satisfaction and productivity and serve as an additional tool for traffic congestion reduction and air quality improvement. However, these assumptions are not explored in this study, but are suggested for future empirical research. Finally, the effects of teleworking into an intrahousehold allocation collective model are suggested for future research applications. More specifically, its effects on labour supply of couples including the household domestic production and considering teleworking can be examined. Most of the previous research have considered the non-market time as pure leisure (Chiappori, 1988, 1992); however, this may give misleading estimates of the labour supply and household allocation and thus the policies can be also inefficient. Considering teleworking and the time use on household domestic production, a new theoretical framework can be developed suggesting new policies, including also people with health problems and disability.

\section{Acknowledgements}

This work was supported by the Marie Skłodowska-Curie Individual Fellowship (IF) grant [652938-TELE]. The author gratefully acknowledges the funding provided by European Commission to carry out this research.

This work was based on data from the British Household Panel Survey (BHPS), Waves 1-18, 1991-2009 Local Authority Districts, and the Understanding Society Survey (USS), Waves 14, 2009-2013 Local Authority Districts, produced by the Institute for Social and Economic Research (ISER) at the University of Essex, sponsored by the Economic and Social Research Council (ESRC), and supplied by the UK Data Archive. The data are the copyright of ISER. The use of the data in this work does not imply the endorsement of ISER, ESRC or the UK Data Archive in relation to the interpretation or analysis of the data. 


\section{References}

Anderson, G., Brosnan, P. and Walsh, P. (1994) 'Homeworking in New Zealand: results from a workplace survey', International Journal of Employment Studies, Vol. 2, No. 2, pp. 229 247.

Barnett, R. C. and Rivers, C. (1996) She works, he works: How two-income families are happy, healthy, and thriving. Cambridge, MA: Harvard University Press, USA.

Barnett, R. C. and Gareis, K. C. (2007) 'Shift work, parenting behaviors, and children's socioemotional well-being: A within-family study', Journal of Family Issues, Vol. 28, No. 6, pp. 727- 748 .

Bauernschuster, S. and Rainer, H. (2010) 'From Politics to the Family: How Sex-Role Attitudes Keep on Diverging in Reunified Germany', CESifo Working Paper No. 2957, Munich, Germany.

Becker, G. S. (1981) A treatise on the family. Cambridge, MA: Harvard University Press, USA

Benjamin, O. and Sullivan, O. (1996) 'The importance of difference: conceptualising increased flexibility in gender relations in the home', Sociological Review, Vol. 44, No. 2, pp. 225251.

Bloom, N., Liang, J., Roberts, J. and Ying, Z.J. (2015) 'Does working from home work? Evidence from a Chinese experiment', Quarterly Journal of Economics, Vol. 130, No. 1, pp. 165-218.

Bryson, R., Bryson, J. B. and Johnson, M.F. (1978) 'Family size, satisfaction and productivity in two-earner couples', Psychology of Women Quarterly, Vol. 3, No. 1, pp. 67-77.

Chiappori, P.A. (1988) 'Rational Household Labor Supply', Econometrica, Vol. 56, No. 1, pp. 63-90.

Chiappori, P.A. (1992) 'Collective Labor Supply and Welfare', Journal of Political Economy, Vol.100, No. 3, pp. 437-446.

Coltrane, S. (1989) 'Household labour and the routine production of gender', Social Problems, Vol. 36, No. 5, pp. 473-490.

Cornelissen, T. (2006) 'Job characteristics as determinants of job satisfaction and labour mobility', Discussion Paper No. 334, Institute of Quantitative Economic Research, University of Hannover, Germany.

Denmark, F. L., Shaw, J. S. and Ciali, S.D. (1985) 'The relationship among sex roles, living arrangements and the division of household responsibilities', Sex Roles, Vol. 12, No. 5-6, pp. 617-625.

Dockery, A.M. and Bawa, S. (2014) 'Is working from home good work or bad work? Evidence from Australian employees', Australian Journal of Labour Economics, Vol. 17, No. 2, pp. 163-190.

Dutcher, E.G. (2012) 'The effects of telecommuting on productivity: an experimental examination - the role of dull and creative tasks', Journal of Economic Behavior and Organization, Vol. 84, No. 1, pp. 355-363

Greenhaus, J. H., Bedeian, A. G. and Mossholder, K. W. (1987) 'Work experiences, job performance, and feelings of personal and family well-being', Journal of Vocational Behavior, 31, No. 2, pp. 200-215.

Gronau, R. (1977) 'Leisure, Home Production, and Work--the Theory of the Allocation of Time Revisited', Journal of Political Economy, Vol. 85, No. 6, pp. 1099-1123.

Han, W. J. (2004) 'Nonstandard work schedules and child care decisions: Evidence from the NICHD study of early child care', Early Childhood Research Quarterly, Vol. 19, No. 2, pp. 231-256. 
Hersch, J. and Stratton, L.S. (1994) 'Housework, Wages, and the Division of Housework Time for Employed Spouses', The American Economic Review: Papers \& Proceedings, Vol. 84, No. 2, pp. 120-125.

Hochschild, A.R. (1997). The time bind: When work becomes home and home becomes work. New York: Metropolitan Books.

Hsiao, C., Mountain, D. C. and Ho Illman, K. (1995) 'Bayesian integration of end-use metering and conditional demand analysis', Journal of Business and Economic Statistics, Vol. 13, No. 3, pp. 315-326.

Keith, P.M. and Schafer, R. B. (1984) 'Role behavior and psychological well-being: A comparison of men in one-job and two-job families', American Journal of Orthopsychiatry, Vol. 54, No. 1, pp. 137-154.

Lerner, J. V. (1994) Working women and their families. Thousand Oaks, CA: Sage, California, USA.

Li, J., Johnson, S., Han, W., Andrews, S., Strazdins, L., Kendall, G. and Dockery, A. (2014) 'Parents' Non-standard Work Schedules and Child Wellbeing. A Critical Review of the Literature', Journal of Primary Prevention, Vol. 35, No. 1, pp. 53-73

Lim, K. G., Thompson, S.H. and Hat, W.S. (1997) 'Working at home- Myth or reality: An empirical study of factors affecting attitudes towards teleworking', Research Paper Series, Faculty of Business Administration, National University of Singapore, Singapore.

Oettinger, G.S. (2011) 'The incidence and wage consequences of home-based work in the United States, 1980-2000', Journal of Human Resources, Vol. 46, No. 2, pp. 237-260.

Ozdamar, O. (2015a) 'Does Public Spending on Parental Leave Benefits Promote Child Health? Evidence from Panel Data Analyses of OECD Countries', International Journal of Economic Perspectives, Vol. 9, No. 1, pp. 32-49.

Ozdamar, O. (2015b) 'Gendered Economic Policy Making: The Case of Public Expenditures on Family Allowances', Economics Discussion Papers, No 2015-37, Kiel Institute for the World Economy, Kiel, Germany

Marks, N.F. (1996) 'Caregiving across the lifespan: National prevalence and predictors', Family Relations, Vol. 45, No. 1, pp. 27-36.

Nilles, J.M. (1975) 'Telecommunications and organizational decentralization', IEEE Transactions On Communications, Vol. 23, No. 10, pp. 1142-1147.

Nilles, J. M. (1999) 'What does telework really do to us?' World Transport Policy and Practice, Vol. 15, No. 2, pp. 1-2.

Pakes, A. and Griliches, Z. (1984) 'Estimating distributed lags in short panels with an application to the specification of depreciation patterns and capital stock constructs', Review of Economic Studies, Vol. 51, No. 2, pp. 243-262.

Pina, D. L. and Bengston, V.L. (1993) 'The Division of Household Labor and Wives' Happiness: Ideology, Employment and Perceptions of Support', Journal of Marriage and the Family, Vol. 55, No. 4, pp. 901-912.

Pischke, J.S. (2011) 'Money and Happiness: Evidence from the Industry Wage Structure', Discussion Paper No. 5705, IZA, Bonn, Germany.

Pischke, J. and Schwandt, H. (2012) 'A cautionary note on using industry affiliation to predict income', Centre for Economic Performance Discussion Paper No 1163. London School of Economics, London.

Rapoport, B. and Le Bourdais, C. (2008). Parental time and working schedules. Journal of Population Economics, Vol. 21, No. 4, pp. 903-932.

Thompson, L. (1991) 'Family Work: Women's Sense of Fairness', Journal of Family Issues, Vol. 12, No. 2, pp. 181-196.

Van Praag, B.M.S. and Ferrer-i-Carbonell, A. (2004) Happiness quantified: A satisfaction calculus approach. Oxford: Oxford University Press, United Kingdom. 
Van Soest, A. (1995) 'Structural models of family labor supply: A discrete choice approach', Journal of Human Resources, Vol. 30, No. 1, pp. 63-88.

Waldfogel, J. (1998) 'Understanding the 'Family Gap'' in Pay for Women with Children', Journal of Economic Perspectives, Vol. 12, No. 1, pp. 137-156.

Warde, A. and Hetherington, K. (1993) 'A changing domestic division of labour? Issues of measurement and interpretation', Work, Employment and Society, Vol. 7, No. 1, pp. 2345.

Wight, V. R., Raley, S. B. and Bianchi, S. M. (2008) 'Time for children, one's spouse and oneself among parents who work nonstandard hours', Social Forces, Vol. 87, No. 1, pp. 243-271.

Willinger, B. (1993) Resistance and change: College men's attitudes toward family and work in the 1980s. In J. C. Hood (Eds.), Men, work, and family, pp. 108-130. Newbury Park, CA: Sage.

. Table 1. Summary Statistics

\begin{tabular}{|c|c|c|c|c|c|}
\hline & \multicolumn{5}{|c|}{ Panel A: Teleworkers } \\
\hline & $\begin{array}{c}\text { Both } \\
\text { teleworkers } \\
\text { and non- } \\
\text { teleworkers }\end{array}$ & $\begin{array}{c}\text { Total } \\
\text { teleworkers }\end{array}$ & $\begin{array}{c}\text { Home-based only } \\
\text { teleworkers }\end{array}$ & $\begin{array}{l}\text { Teleworkers } \\
\text { (more than } \\
\text { one place) }\end{array}$ & Non-teleworkers \\
\hline Total sample & & 11.22 & 3.42 & 7.80 & 88.78 \\
\hline Men & 47.53 & 13.51 & 3.20 & 10.31 & 86.49 \\
\hline \multirow[t]{3}{*}{ Women } & 52.47 & 9.01 & 3.79 & 5.22 & 90.99 \\
\hline & \multicolumn{5}{|c|}{ Panel B: Gender Roles for Men Non-Teleworkers } \\
\hline & $\begin{array}{c}\text { Who does the } \\
\text { grocery } \\
\text { shopping? }\end{array}$ & $\begin{array}{l}\text { Who does the } \\
\text { cooking? }\end{array}$ & $\begin{array}{l}\text { Who does the } \\
\text { cleaning? }\end{array}$ & $\begin{array}{l}\text { Who does the } \\
\text { ironing? }\end{array}$ & $\begin{array}{c}\text { Who is responsible } \\
\text { for childcare? }\end{array}$ \\
\hline Mostly self & 11.02 & 11.89 & 5.92 & 5.2 & 1.28 \\
\hline Mostly partner & 46.46 & 59.57 & 62.14 & 71.04 & 33.47 \\
\hline Shared & 40.47 & 26.89 & 26.73 & 21.56 & 22.33 \\
\hline \multirow[t]{3}{*}{ Paid Help Only or else } & 2.05 & 1.65 & 5.21 & 2.2 & 42.92 \\
\hline & \multicolumn{5}{|c|}{ Panel C: Gender Roles for Women Non-Teleworkers } \\
\hline & $\begin{array}{c}\text { Who does the } \\
\text { grocery } \\
\text { shopping? }\end{array}$ & $\begin{array}{l}\text { Who does the } \\
\text { cooking? }\end{array}$ & $\begin{array}{l}\text { Who does the } \\
\text { cleaning? }\end{array}$ & $\begin{array}{c}\text { Who does the } \\
\text { ironing? }\end{array}$ & $\begin{array}{c}\text { Who is responsible } \\
\text { for childcare? }\end{array}$ \\
\hline Mostly self & 52.97 & 60.27 & 62.39 & 73.29 & 30.61 \\
\hline Mostly partner & 9.92 & 11.66 & 6.43 & 4.05 & 2.98 \\
\hline Shared & 35.94 & 25.98 & 24.07 & 19.32 & 21.03 \\
\hline \multirow[t]{3}{*}{ Paid Help Only or else } & 1.17 & 2.09 & 7.11 & 3.34 & 45.38 \\
\hline & \multicolumn{5}{|c|}{ Panel D: Gender Roles for Men Teleworkers } \\
\hline & $\begin{array}{c}\text { Who does the } \\
\text { grocery } \\
\text { shopping? }\end{array}$ & $\begin{array}{c}\text { Who does the } \\
\text { cooking? }\end{array}$ & $\begin{array}{l}\text { Who does the } \\
\text { cleaning? }\end{array}$ & $\begin{array}{c}\text { Who does the } \\
\text { ironing? }\end{array}$ & $\begin{array}{c}\text { Who is responsible } \\
\text { for childcare? }\end{array}$ \\
\hline \multirow[t]{2}{*}{ Mostly self } & 10.30 & 11.70 & 6.71 & 6.54 & 5.16 \\
\hline & $(0.1830)$ & $(0.5960)$ & $(0.3688)$ & $(0.3681)$ & $(0.0000)$ \\
\hline \multirow[t]{2}{*}{ Mostly partner } & 51.02 & 57.13 & 60.08 & 69.81 & 30.47 \\
\hline & $(0.0000)$ & $(0.0606)$ & $(0.0817)$ & $(0.0017)$ & $(0.0325)$ \\
\hline \multirow[t]{2}{*}{ Shared } & 36.91 & 29.42 & 28.70 & 20.76 & 25.46 \\
\hline & $(0.0000)$ & $(0.0315)$ & $(0.0088)$ & $(0.0115)$ & $(0.0757)$ \\
\hline \multirow[t]{4}{*}{ Paid Help Only or else } & 1.77 & 1.75 & 4.51 & 2.89 & 38.91 \\
\hline & $(0.4258)$ & $(0.5032)$ & $(0.0013)$ & $(0.7705)$ & $(0.2377)$ \\
\hline & \multicolumn{5}{|c|}{ Panel E: Gender Roles for Women Teleworkers } \\
\hline & $\begin{array}{c}\text { Who does the } \\
\text { grocery } \\
\text { shopping? }\end{array}$ & $\begin{array}{c}\text { Who does the } \\
\text { cooking? }\end{array}$ & $\begin{array}{l}\text { Who does the } \\
\text { cleaning? }\end{array}$ & $\begin{array}{l}\text { Who does the } \\
\text { ironing? }\end{array}$ & $\begin{array}{c}\text { Who is responsible } \\
\text { for childcare? }\end{array}$ \\
\hline Mostly self & 58.26 & 63.54 & 66.25 & 74.21 & 32.86 \\
\hline & $(0.0000)$ & $(0.0001)$ & $(0.0006)$ & $(0.3262)$ & $(0.0048)$ \\
\hline Mostly partner & 9.93 & 10.98 & 5.66 & 3.91 & 3.11 \\
\hline
\end{tabular}




\begin{tabular}{|c|c|c|c|c|c|}
\hline \multirow{3}{*}{ Shared } & $(0.8336)$ & $(0.0896)$ & $(0.0038)$ & $(0.7133)$ & $(0.6845)$ \\
\hline & 30.24 & 23.86 & 22.55 & 18.71 & 18.23 \\
\hline & $(0.0000)$ & $(0.0113)$ & $(0.000)$ & $(0.3306)$ & $(0.0001)$ \\
\hline \multirow[t]{5}{*}{ Paid Help Only or else } & 1.57 & 1.62 & 5.54 & 3.17 & 45.80 \\
\hline & $(0.0460)$ & $(0.0551)$ & $(0.0001)$ & $(0.2590)$ & $(0.6145)$ \\
\hline & \multicolumn{5}{|c|}{ Panel F: Weekly Housework hours, Labour Market Hours, Income and Happiness } \\
\hline & Men & Women & Men Non- & Women Non- & \\
\hline & Teleworkers & Teleworkers & Teleworkers & Teleworkers & \\
\hline $\begin{array}{c}\text { Average Weekly Housework } \\
\text { hours }\end{array}$ & 7.162 & 16.201 & 5.233 & 14.316 & \\
\hline $\begin{array}{l}\text { Average Weekly Market } \\
\text { Labour hours }\end{array}$ & 37.286 & 25.617 & 38.248 & 28.514 & \\
\hline Monthly Personal Income & $2,238.004$ & $1,336.884$ & $2,108.141$ & $1,378.982$ & \\
\hline Monthly Household Income & $3,357.823$ & $3,368.338$ & $3,256.206$ & 3179.008 & \\
\hline Happiness & 3.022 & 3.158 & 2.981 & 3.021 & \\
\hline
\end{tabular}

p-values within brackets

Table 2. Correlation Matrix

\begin{tabular}{|c|c|c|c|c|c|c|c|c|c|}
\hline & Teleworking & $\begin{array}{c}\text { Housework } \\
\text { hours }\end{array}$ & Shopping & Cooking & Cleaning & Ironing & Childcare & Happiness & $\begin{array}{l}\text { Personal } \\
\text { Income }\end{array}$ \\
\hline $\begin{array}{l}\text { Housework } \\
\text { hours }\end{array}$ & $\begin{array}{c}0.0381 * * * \\
(0.000)\end{array}$ & & & & & & & & \\
\hline Shopping & $\begin{array}{c}-0.0199 * * * \\
(0.000)\end{array}$ & $\begin{array}{c}-0.0396 * * * \\
(0.000)\end{array}$ & & & & & & & \\
\hline Cooking & $\begin{array}{c}0.0078 * * \\
(0.0357)\end{array}$ & $\begin{array}{c}-0.0456 * * * \\
(0.000)\end{array}$ & $\begin{array}{c}0.2348 * * * \\
(0.000)\end{array}$ & & & & & & \\
\hline Cleaning & $\begin{array}{c}0.0099 * * * \\
(0.0020)\end{array}$ & $\begin{array}{c}-0.0405 * * * \\
(0.000)\end{array}$ & $\begin{array}{c}0.2095 * * * \\
(0.000)\end{array}$ & $\begin{array}{c}0.2402 * * * \\
(0.000)\end{array}$ & & & & & \\
\hline Ironing & $\begin{array}{l}0.0026^{*} \\
(0.0015)\end{array}$ & $\begin{array}{c}-0.0569 * * * \\
(0.000)\end{array}$ & $\begin{array}{c}0.1413 * * * \\
(0.000)\end{array}$ & $\begin{array}{c}0.2150 * * * \\
(0.000)\end{array}$ & $\begin{array}{c}0.3272 * * * \\
(0.000)\end{array}$ & & & & \\
\hline Childcare & $\begin{array}{l}0.0072 * \\
(0.0852)\end{array}$ & $\begin{array}{c}-0.0186^{* * *} \\
(0.000)\end{array}$ & $\begin{array}{c}0.0419 * * * \\
(0.000)\end{array}$ & $\begin{array}{c}0.1079 * * * \\
(0.000)\end{array}$ & $\begin{array}{c}0.0717 * * * \\
(0.000)\end{array}$ & $\begin{array}{c}0.0865 * * * \\
(0.000)\end{array}$ & & & \\
\hline Happiness & $\begin{array}{l}0.0043 * * \\
(0.0021)\end{array}$ & $\begin{array}{c}-0.0374 * * * \\
(0.000)\end{array}$ & $\begin{array}{c}0.0246 * * * \\
(0.000)\end{array}$ & $\begin{array}{c}0.0098 * * * \\
(0.000)\end{array}$ & $\begin{array}{c}0.0193 * * * \\
(0.000)\end{array}$ & $\begin{array}{c}0.0176^{* * * *} \\
(0.000)\end{array}$ & $\begin{array}{c}0.0144 * * \\
(0.0251)\end{array}$ & & \\
\hline $\begin{array}{l}\text { Personal } \\
\text { Income }\end{array}$ & $\begin{array}{c}0.0670 * * * \\
(0.000)\end{array}$ & $\begin{array}{c}-0.2811 * * * \\
(0.000)\end{array}$ & $\begin{array}{c}-0.0430 * * * \\
(0.000)\end{array}$ & $\begin{array}{c}0.0411 * * * \\
(0.000)\end{array}$ & $\begin{array}{c}-0.0055^{* *} \\
(0.0342)\end{array}$ & $\begin{array}{c}0.0701 * * * \\
(0.000)\end{array}$ & $\begin{array}{c}0.0772 * * * \\
(0.000)\end{array}$ & $\begin{array}{c}0.0316 * * * \\
(0.000)\end{array}$ & \\
\hline $\begin{array}{l}\text { Household } \\
\text { Income }\end{array}$ & $\begin{array}{c}0.0257 * * * \\
(0.000)\end{array}$ & $\begin{array}{c}-0.0886^{* * * *} \\
(0.000)\end{array}$ & $\begin{array}{c}-0.0766 * * * \\
(0.000)\end{array}$ & $\begin{array}{c}0.0398 * * * \\
(0.000)\end{array}$ & $\begin{array}{c}-0.0179 * * * \\
(0.000)\end{array}$ & $\begin{array}{c}0.0805 * * * \\
(0.000)\end{array}$ & $\begin{array}{c}0.0758 * * * \\
(0.000)\end{array}$ & $\begin{array}{c}0.0279 * * * \\
(0.000)\end{array}$ & $\begin{array}{c}0.6851 * * * \\
(0.000)\end{array}$ \\
\hline
\end{tabular}

Table 3. Teleworking and Housework Hours Fixed Effects Estimates

\begin{tabular}{ccccc}
\hline & \multicolumn{2}{c}{ Fixed Effects } & \multicolumn{2}{c}{ IV-Fixed Effects } \\
\hline & Men & Women & Men & Women \\
\hline Teleworker (Man) & $1.0782^{* *}$ & $-0.4081^{*}$ & $1.2472^{* *}$ & $-0.5096^{*}$ \\
& $(0.4254)$ & $(0.2271)$ & $(0.5413)$ & $(0.2668)$ \\
Teleworker (Woman) & -0.8044 & $1.5043^{* *}$ & -0.9339 & $1.8843^{* *}$ \\
& $(0.7317)$ & $(0.6356)$ & $(0.6413)$ & $(0.7003)$ \\
No. observations & 25,280 & 25,280 & 25,062 & 25,062 \\
R Square & 0.1489 & 0.1795 & 0.1097 & 0.1557 \\
Weak Instrument Test & & & 51.190 & 46.612 \\
Sargan exogeneity test & & & {$[0.000]$} & {$[0.0001]$} \\
& & & 11.437 & 15.410 \\
& & & $0.2940]$ & {$[0.2285]$} \\
\hline
\end{tabular}

Robust standard errors within brackets, p-values within square brackets, $* *$ and $*$ indicate significance at $5 \%$ and $10 \%$ level 
Table 4. Teleworking and Cooking Multinomial Logit Fixed Effects Estimates

\begin{tabular}{|c|c|c|c|c|}
\hline & \multicolumn{2}{|c|}{ Panel A: Men } & \multicolumn{2}{|c|}{ Panel B: Women } \\
\hline & $\begin{array}{l}\text { Outcome: } \\
\text { Mostly Self }\end{array}$ & $\begin{array}{c}\text { Outcome: } \\
\text { Shared }\end{array}$ & $\begin{array}{l}\text { Outcome: } \\
\text { Mostly Self }\end{array}$ & $\begin{array}{c}\text { Outcome: } \\
\text { Shared }\end{array}$ \\
\hline \multirow[t]{2}{*}{ Teleworker (Man) } & 0.0068 & $0.0253 *$ & -0.0299 & $-0.1143 * *$ \\
\hline & $(0.0581)$ & $(0.0131)$ & $(0.0717)$ & $(0.0509)$ \\
\hline \multirow[t]{2}{*}{ Teleworker (Woman) } & 0.0451 & $0.1158 *$ & 0.0542 & $-0.1797 * *$ \\
\hline & $(0.0982)$ & $(0.0667)$ & $(0.0564)$ & $(0.0706)$ \\
\hline \multirow[t]{2}{*}{ Labour Income (Man) } & $-0.2737 * * *$ & $-0.3040 * * *$ & $0.2867 * * *$ & $-0.3808 * * *$ \\
\hline & $(0.0585)$ & $(0.0417)$ & $(0.0632)$ & $(0.0432)$ \\
\hline \multirow[t]{2}{*}{ Labour Income (Woman) } & $0.5213 * * *$ & $0.3918 * * *$ & $-0.5141 * * *$ & $0.2928 * * *$ \\
\hline & $(0.0581)$ & $(0.0402)$ & $(0.0626)$ & $(0.0414)$ \\
\hline \multirow[t]{2}{*}{ Number of Market Hours (Man) } & $-0.0127 * * *$ & $-0.0057 * * *$ & $0.0176 * * *$ & $-0.0072 * * *$ \\
\hline & $(0.0029)$ & $(0.0020)$ & $(0.0031)$ & $(0.0023)$ \\
\hline \multirow{2}{*}{ Number of Market Hours (Woman) } & $0.0181 * * *$ & $0.0136^{* * *}$ & $-0.0243 * * *$ & $0.0222 * * *$ \\
\hline & $(0.0033)$ & $(0.0020)$ & $(0.0031)$ & $(0.0021)$ \\
\hline \multirow[t]{2}{*}{ Age (Man) } & -0.0043 & 0.0009 & 0.0059 & $0.0064 *$ \\
\hline & $(0.0047)$ & $(0.0034)$ & $(0.0045)$ & $(0.0035)$ \\
\hline \multirow[t]{2}{*}{ Age (Woman) } & $-0.0339 * * *$ & $-0.0246 * * *$ & $-0.0385 * * *$ & $0.0165^{* * *}$ \\
\hline & $(0.0047)$ & $(0.0035)$ & $(0.0051)$ & $(0.0051)$ \\
\hline \multicolumn{5}{|l|}{ Marital Status $($ Reference $=$ married $)$} \\
\hline Marital Status (Living as a couple) & $\begin{array}{c}0.2348 * * * \\
(0.0598)\end{array}$ & $\begin{array}{l}0.1446 * * * \\
(0.0453)\end{array}$ & $\begin{array}{c}0.2735 * * * \\
(0.0619)\end{array}$ & $\begin{array}{l}0.0871 * \\
(0.0459)\end{array}$ \\
\hline \multicolumn{5}{|l|}{ Job Status Man (Reference=Self-Employed) } \\
\hline \multirow[t]{2}{*}{ Job Status Man (Employee) } & 0.4194 & 0.1089 & .04557 & 0.3814 \\
\hline & $(0.6752)$ & $(0.2883)$ & $(0.3556)$ & $(0.2863)$ \\
\hline \multicolumn{5}{|l|}{ Job Status Woman (Reference=Self-Employed) } \\
\hline Job Status Woman (Employee) & $\begin{array}{l}1.7074 \\
(1.9186)\end{array}$ & $\begin{array}{l}-0.3225 \\
(0.4345)\end{array}$ & $\begin{array}{c}-1.0426 * * \\
(0.4375)\end{array}$ & $\begin{array}{c}0.2385 \\
(0.4590)\end{array}$ \\
\hline \multicolumn{5}{|l|}{$\begin{array}{c}\text { Education Level Man (Reference=Higher } \\
\text { Degree) }\end{array}$} \\
\hline \multirow[t]{2}{*}{ Education Level Man ( $1^{\text {st }}$ Degree $)$} & $-0.4187 *$ & -0.1356 & $0.2618 * *$ & $-0.2115 * *$ \\
\hline & $(0.2222)$ & $(0.0846)$ & $(0.1194)$ & $(0.0949)$ \\
\hline \multirow[t]{2}{*}{ Education Level Man (None) } & $-0.5848 * *$ & $-0.1972 * *$ & $0.3480 * *$ & $-0.2884 * *$ \\
\hline & $(0.2861)$ & $(0.0864)$ & $(0.1375)$ & $(0.1383)$ \\
\hline \multicolumn{5}{|l|}{$\begin{array}{c}\text { Education Level Woman }(\text { Reference }=\text { Higher } \\
\text { Degree })\end{array}$} \\
\hline \multirow[t]{2}{*}{ Education Level Woman ( $1^{\text {st }}$ Degree $)$} & -0.2628 & -0.1697 & -0.2101 & -0.1047 \\
\hline & $(0.3889)$ & $(0.1152)$ & $(0.1578)$ & $(0.0977)$ \\
\hline \multirow[t]{2}{*}{ Education Level Woman (None) } & $-0.3789 *$ & $-0.5850 * * *$ & $-0.2535^{*}$ & $-0.1982 *$ \\
\hline & $(0.1901)$ & $(0.1073)$ & $(0.1342)$ & $(0.1083)$ \\
\hline Health Status Man $($ Reference $=$ Very Goo & & & & \\
\hline Health Status man (Very Bad) & -0.3740 & -0.2441 & 0.1910 & $-0.3756 * * *$ \\
\hline & $(0.2634)$ & $(0.2520)$ & $(0.1340)$ & $(0.1056)$ \\
\hline Health Status Woman $($ Reference $=$ Very Go & & & & \\
\hline Health Status Woman (Very Bad) & $0.6236^{* *}$ & $0.4107 * *$ & $-0.7504 * * *$ & $0.4885^{* *}$ \\
\hline & $(0.2878)$ & $(0.1951)$ & $(0.2506)$ & $(0.2224)$ \\
\hline Household Size & $0.1152 * * *$ & $-0.0356^{* *}$ & $-0.1014 * * *$ & $-0.0661 * * *$ \\
\hline & $(0.0208)$ & $(0.0164)$ & $(0.0293)$ & $(0.0171)$ \\
\hline House Tenure (Reference $=$ Owned Outrig & & & & \\
\hline House Tenure (Owned with Mortgage) & 0.1805 & 0.0210 & $0.2027 * *$ & 0.0353 \\
\hline & $(0.2263)$ & $(0.0485)$ & $(0.0985)$ & $(0.0607)$ \\
\hline No. observations & 23,196 & & 23,196 & \\
\hline LR chi square & $3,261.89$ & & $3,183.96$ & \\
\hline & {$[0.000]$} & & {$[0.000]$} & \\
\hline
\end{tabular}


Table 5. Teleworking and rest of Gender Roles Multinomial Fixed Effects Estimates

\begin{tabular}{|c|c|c|c|c|}
\hline & \multicolumn{2}{|c|}{ Panel A: Men } & \multicolumn{2}{|c|}{ Panel B: Women } \\
\hline & $\begin{array}{l}\text { Outcome: } \\
\text { Mostly Self }\end{array}$ & $\begin{array}{l}\text { Outcome: } \\
\text { Shared }\end{array}$ & $\begin{array}{l}\text { Outcome: } \\
\text { Mostly Self }\end{array}$ & $\begin{array}{c}\text { Outcome: } \\
\text { Shared }\end{array}$ \\
\hline & \multicolumn{4}{|c|}{ Shopping } \\
\hline Teleworker (Man) & $\begin{array}{c}-0.0538 \\
(0.0487)\end{array}$ & $\begin{array}{l}-0.1132 * \\
(0.0637)\end{array}$ & $\begin{array}{c}0.1678^{*} * \\
(0.0804)\end{array}$ & $\begin{array}{c}-0.2235 * * * \\
(0.0451)\end{array}$ \\
\hline Teleworker & -0.1275 & $-0.1834 * *$ & $-0.1300^{*}$ & $-0.1724 * *$ \\
\hline (Woman) & $(0.1167)$ & $(0.0912)$ & $(0.0726)$ & $(0.0819)$ \\
\hline No. Observations & 23,196 & & 23,196 & \\
\hline \multirow[t]{3}{*}{ LR chi square } & $3,990.28$ & & $4,034.09$ & \\
\hline & {$[0.000]$} & & {$[0.000]$} & \\
\hline & \multicolumn{4}{|c|}{ Cleaning } \\
\hline \multirow[t]{2}{*}{ Teleworker (Man) } & 0.0665 & $0.0233 * *$ & -0.1031 & $0.0327 * *$ \\
\hline & $(0.0881)$ & $(0.0104)$ & $(0.1044)$ & $(0.0161)$ \\
\hline Teleworker & $-0.2395 * *$ & -0.0987 & $0.4246 * *$ & 0.0363 \\
\hline (Woman) & $(0.1149)$ & $(0.0711)$ & $(0.1682)$ & $(0.0475)$ \\
\hline No. Observations & 23,196 & & 23,196 & \\
\hline \multirow[t]{3}{*}{ LR chi square } & $4,428.57$ & & $4,831.45$ & \\
\hline & {$[0.000]$} & & {$[0.000]$} & \\
\hline & \multicolumn{4}{|c|}{ Ironing } \\
\hline \multirow[t]{2}{*}{ Teleworker (Man) } & $0.2344^{*}$ & -0.0491 & 0.1120 & $0.1141 * *$ \\
\hline & $(0.1277)$ & $(0.0543)$ & $(0.1192)$ & $(0.0569)$ \\
\hline Teleworker & 0.0929 & $0.1302 *$ & $0.1617^{*}$ & $-0.1749 * *$ \\
\hline (Woman) & $(0.0937)$ & $(0.0752)$ & $(0.0883)$ & $(0.0771)$ \\
\hline No. Observations & 23,196 & & 23,196 & \\
\hline \multirow[t]{3}{*}{ LR chi square } & $3,991.06$ & & $4,434.02$ & \\
\hline & {$[0.000]$} & & {$[0.000]$} & \\
\hline & \multicolumn{4}{|c|}{ Childcare } \\
\hline \multirow[t]{2}{*}{ Teleworker (Man) } & $1.0185^{* * *}$ & $0.1090 *$ & $-0.1579 * *$ & $0.2347 * *$ \\
\hline & $(0.1477)$ & $(0.0605)$ & $(0.0613)$ & $(0.1133)$ \\
\hline Teleworker & $-0.7107 * * *$ & -0.0245 & -0.0534 & 0.0415 \\
\hline (Woman) & $(0.2082)$ & $(0.0883)$ & $(0.0908)$ & $(0.0932)$ \\
\hline No. Observations & 18,838 & & 18,838 & \\
\hline \multirow[t]{2}{*}{ LR chi square } & $8,769.76$ & & $9,108.24$ & \\
\hline & {$[0.000]$} & & {$[0.000]$} & \\
\hline
\end{tabular}

Robust standard Errors within brackets, p-values within square brackets, ${ }^{* * *},{ }^{* *}$ and $*$ indicate significance at $1 \%, 5 \%$ and $10 \%$ level 
Table 6. Probit-OLS Fixed Effects Happiness Function Estimates

\begin{tabular}{|c|c|c|c|c|}
\hline & \multicolumn{2}{|c|}{ Couples with Children } & \multicolumn{2}{|c|}{ Couples without Children } \\
\hline & $\begin{array}{l}\text { DV: Men } \\
\text { Happiness }\end{array}$ & $\begin{array}{l}\text { DV: Women } \\
\text { Happiness }\end{array}$ & $\begin{array}{l}\text { DV: Men } \\
\text { Happiness }\end{array}$ & $\begin{array}{l}\text { DV: Women } \\
\text { Happiness }\end{array}$ \\
\hline \multirow{2}{*}{ Teleworker (Man) } & 0.0453 & $0.0418 * *$ & 0.0409 & $0.0446^{* *}$ \\
\hline & $(0.0409)$ & $(0.0183)$ & $(0.0302)$ & $(0.0219)$ \\
\hline \multirow[t]{2}{*}{ Teleworker (Woman) } & $0.0712 * *$ & $0.0134^{*}$ & $0.0511 *$ & $0.0117^{*}$ \\
\hline & $(0.0337)$ & $(0.0071)$ & $(0.0237)$ & $(0.0061)$ \\
\hline \multirow[t]{2}{*}{ Housework Hours } & $-0.0025^{* *}$ & $-0.0017^{*}$ & $-0.0026^{*}$ & -0.0014 \\
\hline & $(0.0012)$ & $(0.0009)$ & $(0.0014)$ & $(0.0010)$ \\
\hline \multirow{2}{*}{\multicolumn{5}{|c|}{$\begin{array}{c}\text { Shopping Respondent (Base } \\
\text { Outcome=mainly myself) }\end{array}$}} \\
\hline & & & & \\
\hline \multirow{2}{*}{$\begin{array}{c}\text { Shopping Respondent (Mainly my } \\
\text { partner) }\end{array}$} & 0.0101 & $0.0519 * *$ & 0.0126 & $0.0536^{* *}$ \\
\hline & $(0.0167)$ & $(0.0224)$ & $(0.0262)$ & $(0.0257)$ \\
\hline \multirow[t]{2}{*}{ Shopping Respondent (Shared) } & $0.0317 * *$ & 0.0221 & $0.0419 * *$ & $0.0256^{*}$ \\
\hline & $(0.0127)$ & $(0.0252)$ & $(0.0186)$ & $(0.0132)$ \\
\hline \multirow[t]{2}{*}{ Shopping Respondent (Paid Only) } & -0.0192 & -0.0480 & -0.0194 & -0.0909 \\
\hline & $(0.1149)$ & $(0.1022)$ & $(0.1054)$ & $(0.1141)$ \\
\hline \multirow{2}{*}{\multicolumn{5}{|c|}{$\begin{array}{l}\text { Cooking Respondent (Base } \\
\text { Outcome=mainly myself) }\end{array}$}} \\
\hline & & & & \\
\hline \multirow{2}{*}{$\begin{array}{c}\text { Cooking Respondent (Mainly my } \\
\text { partner) }\end{array}$} & 0.0392 & $0.0225^{*}$ & 0.0324 & 0.0320 \\
\hline & $(0.0443)$ & $(0.0121)$ & $(0.0242)$ & $(0.0231)$ \\
\hline \multirow[t]{2}{*}{ Cooking Respondent (Shared) } & $0.0275^{*}$ & $0.0113 * *$ & $0.0383 *$ & $0.0145 * *$ \\
\hline & $(0.0144)$ & $(0.0055)$ & $(0.0197)$ & $(0.0062)$ \\
\hline \multirow[t]{2}{*}{ Cooking Respondent (Paid Only) } & 0.0506 & 0.0803 & 0.0416 & 0.0654 \\
\hline & $(0.1348)$ & $(0.1258)$ & $(0.1088)$ & $(0.1152)$ \\
\hline \multirow{2}{*}{\multicolumn{5}{|c|}{$\begin{array}{l}\text { Cleaning Respondent (Base } \\
\text { Outcome=mainly myself) }\end{array}$}} \\
\hline & & & & \\
\hline \multirow{4}{*}{$\begin{array}{c}\text { Cleaning Respondent (Mainly my } \\
\text { partner) } \\
\text { Cleaning Respondent (Shared) }\end{array}$} & -0.0065 & -0.0096 & -0.0091 & -0.0049 \\
\hline & $(0.0320)$ & $(0.0232)$ & $(0.0319)$ & $(0.0313)$ \\
\hline & 0.0108 & $0.0102 * *$ & 0.0205 & $0.0091 * *$ \\
\hline & $(0.0323)$ & $(0.0041)$ & $(0.0182)$ & $(0.0044)$ \\
\hline \multirow[t]{2}{*}{ Cleaning Respondent (Paid Only) } & -0.0204 & -0.1071 & -0.0218 & -0.0546 \\
\hline & $(0.0489)$ & $(0.0838)$ & $(0.0455)$ & $(0.0480)$ \\
\hline \multirow{2}{*}{\multicolumn{5}{|c|}{$\begin{array}{l}\text { Ironing Respondent (Base } \\
\text { Outcome=mainly myself) }\end{array}$}} \\
\hline & & & & \\
\hline \multirow{2}{*}{$\begin{array}{c}\text { Ironing Respondent (Mainly my } \\
\text { partner) }\end{array}$} & $0.0188 *$ & $0.0805 *$ & $0.0175^{*}$ & $0.0755^{*}$ \\
\hline & $(0.0104)$ & $(0.0413)$ & $(0.0093)$ & $(0.0382)$ \\
\hline \multirow[t]{2}{*}{ Ironing Respondent (Shared) } & $0.0398 *$ & $0.0234 *$ & $0.0359 *$ & $0.0271 *$ \\
\hline & $(0.0195)$ & $(0.0125)$ & $(0.0181)$ & $(0.0138)$ \\
\hline \multirow[t]{2}{*}{ Ironing Respondent (Paid Only) } & -0.0604 & 0.0622 & -0.0519 & 0.0782 \\
\hline & $(0.0549)$ & $(0.0585)$ & $(0.0687)$ & $(0.0675)$ \\
\hline \multirow{2}{*}{\multicolumn{5}{|c|}{$\begin{array}{l}\text { Childcare Respondent (Base } \\
\text { Outcome=mainly myself) }\end{array}$}} \\
\hline & & & & \\
\hline \multirow{2}{*}{$\begin{array}{c}\text { Childcare Respondent (Mainly my } \\
\text { partner) }\end{array}$} & 0.0473 & $0.1246^{* *}$ & & \\
\hline & $(0.0720)$ & $(0.0608)$ & & \\
\hline Childcare Respondent (Shared) & $0.0187 * *$ & $0.0224 * *$ & & \\
\hline & $(0.0078)$ & $(0.0101)$ & & \\
\hline Childcare Respondent (Someone & 0.0143 & $-0.1809^{*}$ & & \\
\hline Else) & $(0.0220)$ & $(0.0911)$ & & \\
\hline No. Observations & 18,838 & 18,838 & 23,196 & 23,196 \\
\hline R Square & 0.1146 & 0.1183 & 0.1033 & 0.1152 \\
\hline
\end{tabular}
Robust Standard Errors within brackets, ${ }^{* *}$ and * indicate significance at $5 \%$ and $10 \%$ level 
Table 7. Probit-IV Fixed Effects Happiness Function Estimates

\begin{tabular}{ccccc}
\hline & \multicolumn{2}{c}{ Couples with Children } & \multicolumn{2}{c}{ Couples without Children } \\
\hline & $\begin{array}{c}\text { DV: Men } \\
\text { Happiness }\end{array}$ & $\begin{array}{c}\text { DV: Women } \\
\text { Happiness }\end{array}$ & $\begin{array}{c}\text { DV: Men } \\
\text { Happiness }\end{array}$ & $\begin{array}{c}\text { DV: Women } \\
\text { Happiness }\end{array}$ \\
\hline Teleworker (Man) & 0.0603 & $0.0562^{* *}$ & 0.0582 & $0.0611^{* *}$ \\
Teleworker (Woman) & $(0.0537)$ & $(0.0259)$ & $(0.0987)$ & $(0.0258)$ \\
& $0.0935^{* *}$ & $0.0195^{*}$ & $0.0787^{* *}$ & $0.0188^{*}$ \\
No. Observations & $(0.0447)$ & $(0.0103)$ & $(0.0371)$ & $(0.0097)$ \\
R Square & 18,646 & 18,646 & 22,894 & 22,894 \\
Weak Instrument Test & 0.1048 & 0.1020 & 0.1054 & 0.1045 \\
Sargan exogeneity test & 44.235 & 38.110 & 42.541 & 38.315 \\
& {$[0.000]$} & {$[0.000]$} & {$[0.000]$} & {$[0.000]$} \\
\hline
\end{tabular}

Robust Standard Errors within brackets, p-values within square brackets, ${ }^{* *}$ and * indicate significance at, $5 \%$ and $10 \%$ level

(C) 2017 by the author; licensee Preprints, Basel, Switzerland. This article is an open access article distributed under the terms and conditions of the Creative Commons by Attribution (CC-BY) license (http://creativecommons.org/licenses/by/4.0/). 